\title{
Deskripsi Kemampuan Literasi Matematis pada Materi Aritmatika Sosial Berdasarkan Gender
}

\author{
Jumarniati ${ }^{1}$, Muhammad Rusli Baharuddin ${ }^{2 *}$, Sulfiana Firman ${ }^{3}$ \\ 1) Pendidikan Matematika, Fakultas Keguruan dan Ilmu Pendidikan, Universitas Cokroaminoto Palopo \\ 2) 3) PGSD, Fakultas Keguruan dan IImu Pendidikan, Universitas Cokroaminoto Palopo \\ ${ }^{2)}$ mruslib@gmail.com

\begin{abstract}
ABSTRAK
Jenis penelitian ini adalah penelitian deskriptif kualitatif yang bertujuan untuk mendeskripsikan kemampuan literasi matematis siswa dalam menyelesaikan soal aritmetika sosial berdasarkan gender. Subjek penelitian dipilih berdasarkan gender yaitu terdiri dari 2 subjek dengan rincian 1 perempuan dan 1 laki-laki siswa sekolah dasar. Instrumen yang digunakan dalam penelitian ini adalah Tes Kemampuan literasi matematis dan pedoman wawancara. Tes Kemampuan numerasi disajikan dalam bentuk soal cerita sebanyak 2 nomor dan setiap nomornya akan mengungkap 4 indikator yaitu (1) Mampu mengidentifikasi masalah, (2) Membuat rencana penyelesaian, (3) Menyelesaikan permasalahan dan (4) Menyimpulkan. Hasil Penelitian menunjukkan Kemampuan literasi Matematis siswa subjek gender perempuan dalam menyelesaikan soal aritmatika sosial menunjukkan bahwa subjek mampu mengerjakan dan menyelesaikan soal sesuai prosedur pengerjaan soal sampai selesai dan mengungkap 4 indikator yaitu mengidentifikasi masalah, merencanakan penyelesaian, menyelesaikan masalah, dan menarik kesimpulan. sedangkan pada subjek laki-laki mengungkap 3 indikator yaitu mengidentifikasi masalah, merencanakan penyelesaian dan menyelesaikan masalah.
\end{abstract}

Kata Kunci: Literasi Matematis, Aritmetika Sosial, Gender, Siswa

\begin{abstract}
This type of research is descriptive qualitative research which aims to describe students' mathematical literacy skills in solving social arithmetic problems based on gender. The research subjects were selected based on gender, which consisted of 2 subjects with details 1 female and 1 male elementary school students. The instruments used in this research are Mathematical Literacy Ability Test and interview guide. The numeracy ability test is presented in the form of story questions as much as 2 numbers and each number will reveal 4 indicators, namely (1) being able to identify problems, (2) making plans for completion, (3) solving problems and (4) concluding. The results showed that the Mathematical literacy ability of female gender subjects in solving social arithmetic problems showed that the subject was able to work on and solve the problem according to the procedure for working on the problem to completion and revealed 4 indicators, namely identifying problems, planning solutions, solving problems, and drawing conclusions. while the male subjects revealed 3 indicators, namely identifying problems, planning solutions and solving problems. In the fourth indicator, male subjects tend not to write conclusions because they perceive the results of the answers that have been previously written.
\end{abstract}

Keywords: Mathematical Literacy, Social Arithmetic, Gender, Students 


\section{A. PENDAHULUAN}

Kemajuan suatu bangsa tidak hanya diukur berdasarkan tingkat perekonomiannya, namun juga ditentukan dari bagaimana perkembangan pendidikan bagi anak-anak bangsanya. Kemajuan yang terukur dalam satuan waktu jangka panjang akan memprediksikan sejauh mana kualitas bangsa pada sekian puluh tahun ke depan. Hasil akhir dari suatu pendidikan yang terencana ialah terwujudnya masyarakat yang berpendidikan tinggi, beretika dan bermanfaat bagi sekelilingnya. Masyarakat suatu negara yang maju akan melahirkan kemajuan dalam berbagai bidang seperti pembangunan, ilmu pengetahuan, teknologi dan lainnya.

Untuk memperoleh pendidikan yang maju, tinggi dan berkembang perlunya suatu perencanaan yang berhubungan dengan tujuan nasional pendidikan bangsa itu. Indonesia dalam Pendidikan Nasional Nomor 20 Tahun 2003 menyatakan bahwa tujuan pendidikan nasional adalah untuk mencetak generasi bangsa yang beriman dan bertakwa, berbudi pekerti luhur, cerdas dan kreatif. Di era industri saat ini, kerasnya tuntutan kehidupan berkembang sangat pesat sehingga untuk menghadapinya diperlu kan adanya pendidikan, baik pendidikan formal maupun informal. Salah satu bidang ilmu yang penting untuk menunjang terwujudnya negara yang maju ialah matematika. Matematika merupakan ilmu yang bersifat universal yang mendasari perkembangan teknologi modern, mempunyai peran penting dalam berbagai disiplin ilmu dan memajukan daya pikir manusia.
Matematika adalah bidang ilmu yang mempelajari tentang kuantitas, besaran, ruang, struktur dan perubahan. Matematika merupakan ilmu pasti yang dihitung dan dirangkai dengan menggunakan pola dan menghasilkan suatu kebenaran melalui metode-metode pembelajaran yang diturunkan dari aksiomaaksioma, teorema-teorema dan definisi-definisi yang sesuai dengan pembahasan. Matematika pertama kali muncul di berbagai negara seperti yang kita ketahui pada tahun 800 SM matematika mulai ada di negara Arab, kemudian pada tahun 300 SM pertama kali ditemukan di dataran Tiongkok hingga di negara India pertama kali ditemukan pada tahun 100 SM. Sejarah mengajarkan kita bahwa matematika terus mengalami perkembangan bahkan hingga era digital saat ini matematika telah menjadi bagian penting bagi peningkatan laju penemuan masa kini. Matematika bukanlah ilmu yang hanya berisi kumpulan simbol dan angka tetapi matematika memiliki pengaruh besar pada perkembangan dunia.

Salah satu karakteristik dari bidang ilmu matematika ialah mempunyai obyek yang bersifat abstrak. Sehingga, dalam pembelajaran matematika ditemukan adanya siswa yang mengalami kesulitan dalam memahami konsep matematika. Ada banyak alasan pentingnya siswa belajar matematika salah satunya adalah sebagai sarana berpikir yang jelas dan logis serta berperan untuk memecahkan masalah dari yang paling sederhana hingga yang paling kompleks. 
Kemampuan literasi matematika merupakan salah satu kemampuan yang dinilai dalam studi PISA. Literasi matematis diartikan sebagai kemampuan seseorang dalam merumuskan, menerapkan dan menafsirkan matematika dalam berbagai situasi termasuk kemampuan melakukan penalaran secara matematis dan kemampuan untuk menggunakan konsep, prosedur dan fakta yang berfungsi untuk menggambarkan, menjelaskan atau memperkirakan fenomena atau kejadian. Literasi matematis dikatakan baik apabila subjek memiliki kemampuan menganalisis, bernalar dan mengkomunikasikan pengetahuan dan keterampilan matematikanya secara efektif serta mampu memecahkan dan menginterpretasikan penyelesaiannya secara matematis.

Kemampuan literasi matematis sangat penting untuk dikembangkan dalam dunia pendidikan matematika. Menurut Jamal (2014) siswa dengan kemampuan literasi matematis yang baik pasti bisa memperkirakan, menginterpretasikan data yang ada, memecahkan masalah dalam kehidupan seharihari, mampu mengemukakan alasan yang bersifat numerik, grafis dan situasi geometris serta berkomunikasi menggunakan bahasa matematika.

Materi yang sangat berkaitan erat dengan kehidupan sehari-hari dikenal dengan nama aritmatika sosial. Aritmatika sosial adalah kegiatan yang berhubungan dengan jual beli yang sering kita jumpai saat berada di pasar tradisional, pasar modern ataupun supermarket.
Fakta bahwa pedagogi yang selesai berjualan akan menghitung hasil penjualannya, untung rugi yang diperoleh, hingga apakah kegiatan yang dilakukan mampu mengembalikan modal awal atau tidak merupakan salah satu konsep dalam kehidupan sehari-hari yang menerapkan aritmatika sosial. Perhitungan aritmatika sosial ini menggunakan konsep aljabar melalui operasi hitung yang berupa pecahan dan yang lain.

Aritmatika sosial adalah sebuah materi yang berisi perhitungan keuangan dalam kehidupan sehari-hari, mempelajari konsep-konsep yang berkaitan dengan jual beli, untung atau rugi, diskon, bunga tunggal, pajak serta segala sesuatu yang berhubungan dengan perdagangan.

Manusia diciptakan menjadi dua jenis yakni perempuan dan laki-laki sebagai dasar pembeda identitas, baik secara fisik, kemampuan dalam matematika, tingkat keunggulan, kelemahan, dan kemampuan sosialnya. Namun, perbedaan jenis kelamin seharusnya tidak menganggap bahwa perempuan lebih unggul atau laki-laki yang lebih unggul. Pada kenyataannya, selama ini perbedaan jenis kelamin telah menjadi salah satu hal yang membedakan perkembangan kognitif manusia yang tentu saja sangat mempengaruhi bagaimana kemampuan berpikir seseorang.

Pembelajaran matematika dipengaruhi oleh banyak faktor. Penelitian yang dilakukan Susanto (2012) mengatakan bahwa "Revealed that people with high $A Q$ out performed those with low $A Q^{\prime \prime}$. Selain $A Q$, faktor lain yang harus diperhatikan dalam mempelajari matematika adalah faktor jenis kelamin siswa (gender). 
Perbedaan gender berarti adanya perbedaan fisiologi dan memengaruhi perbedaan psikologis dalam proses belajar. Hal inilah yang mendasari bahwa siswa laki-laki dan perempuan tentu memiliki banyak perbedaan dalam belajar termasuk dalam mempelajari matematika, menyebabkan terjadinya perbedaan dalam penyelesaian masalah dalam matematika. Namun, ada banyaknya masalah matematika pada tes standar multilangkah dan diperlukannya beberapa pendekatan bersifat sistematis, siswa pada dasarnya bias menemukan solusi yang tepat dengan memilih dan menggabungkan satu set dari strategi yang sesuai.

Berdasarkan hasil observasi awal yang dilakukan di SDN 111 Batusitanduk peneliti menemukan beberapa masalah matematika terkhusus pada kemampuan literasi Matematis siswa dimana masih banyak siswa yang sulit memahami soal untuk diceritakan kembali dalam bentuk matematis, siswa masih kurang dalam menuliskan rumus aritmatika sosial dengan benar, siswa masih kurang dalam menguasai operasi hitung seperti perkalian, pembagian, penjumlahan dan pengurangan. Kesulitan-kesulitan inilah yang menyebabkan siswa sehingga sulit dalam menyelesaikan soal aritmatika sosial.

\section{B. METODE}

Jenis penelitian ini adalah penelitian deskriptif kualitatif yang bertujuan untuk mendeskripsikan kemampuan literasi matematis siswa dalam menyelesaikan soal aritmetika sosial berdasarkan gender. Subjek penelitian dipilih berdasarkan gender yaitu terdiri dari 2 subjek dengan rincian 1 perempuan dan 1 laki-laki siswa Kelas V SDN 111 Batusitanduk. Dalam memilih subjek penelitian, peneliti membagikan tes terlebih dahulu kepada siswa kelas V SDN 111 Batusitanduk. Setelah itu peneliti memeriksa hasil pengerjaan siswa lalu memilih 2 subjek berdasarkan gender yaitu 1 perempuan dan 1 laki-laki yang didasarkan pada sub indikator kemampuan literasi matematis.

Instrumen yang digunakan dalam penelitian ini adalah Tes Kemampuan literasi matematis dan pedoman wawancara. Menurut Roebyant \& Harmini (2017) Tes Kemampuan numerasi disajikan dalam bentuk soal cerita sebanyak 2 nomor dan setiap nomornya akan mengungkap 4 indikator yaitu (1) Mampu mengidentifikasi masalah, (2) Membuat rencana penyelesaian, (3) Menyelesaikan permasalahan dan (4) Menyimpulkan. Pedoman wawancara dilakukan dengan memberikan pertanyaan-pertanyaan yang sudah disusun sebelum melakukan wawancara. Wawancara bertujuan untuk mendapatkan data-data penelitian mengenai kemampuan literasi numerasi siswa.

Teknis analisis data yang digunakan menurut miles dan Huberman (2014) yaitu reduksi data, penyajian data, dan penarikan kesimpulan. Sedangkan untuk menguji keabsahan data maka dilakukan proses triangulasi metode yaitu membandingkan data hasil tes dan data hasil wawancara. 


\section{HASIL DAN PEMBAHASAN}

\section{Hasil Penelitian}

\section{a. Data Subjek Gender Perempuan}

Berdasarkan hasil tes kemampuan literasi matematis subjek gender perempuan mampu mengungkap 4 sub indikator untuk soal nomor 1 terbukti dari subjek mampu menuliskan diketahui, ditanyakan, menuliskan rumus dan menyimpulkan suatu masalah yang ada pada soal. Tetapi untuk soal nomor 2 subjek hanya mampu mengungkap 3 sub indikator kemampuan literasi matematis.

Berdasarkan hasil tes wawancara subjek mampu menjawab dan menjelaskan setiap pertanyaan yang diajukan oleh peneliti seperti subjek mampu menyebutkan apa-apa saja yang diketahui dari soal, apa yang ditanyakan, menyebutkan rumus dan menyelesaikan soal sampai pada tahap kesimpulan dari suatu masalah, tetapi pada soal nomor 2 subjek tidak sampai pada tahap kesimpulan dalam mengerjakan soal dikarenakan waktu untuk menjawab soal telah selesai.

Jadi berdasarkan hasil tes kemampuan literasi dan hasil wawancara dapat disimpulkan bahwa pada soal nomor 1 subjek gender perempuan telah mampu mengungkap 4 sub indikator kemampuan literasi matematis dimana subjek telah mampu mengidentifikasi masalah, telah mampu membuat rencana penyelesaian dengan tepat, telah mampu mengajukan rumus dan menetapkan penyelesaian dari suatu masalah serta subjek telah mampu menyelesaikan dan menyimpulkannya, tetapi pada soal nomor 2 subjek hanya mengungkap 3 sub indikator saja.

\section{b. Data Subjek Gender Laki-Laki}

Berdasarkan hasil tes kemampuan literasi matematis subjek gender laki-laki hanya mampu mengungkap 3 sub indikator saja untuk kedua soal. Subjek hanya menuliskan hal-hal yang diketahui dari soal, hal yang ditanyakan, dan menuliskan rumus. Subjek tidak mengungkap sub indikator yang ke 4 yaitu menyimpulkan suatu permasalahan yang ada pada soal.

Berdasarkan hasil wawancara subjek gender laki-laki mampu menyebutkan hal-hal yang diketahui dan ditanyakan dari soal, subjek juga menyebutkan rumus yang digunakan untuk mengerjakan soal, tidak hanya itu subjek juga menyebutkan alasan mengapa subjek tidak menyelesaikan soal sampai pada tahap kesimpulan.

Jadi dari hasil kemampuan literasi matematis dan hasil wawancara dapat disimpulkan bahwa subjek gender laki-laki hanya mampu mengungkap 3 sub indikator kemampuan literasi matematis, dimana subjek mampu mengidentifikasi masalah, mampu membuat rencana penyelesaian dengan tepat, mampu mengajukan rumus dan menetapkan penyelesaian dari suatu masalah sedangkan pada tahap kesimpulan tidak diselesaikan oleh subjek. 


\section{Pembahasan}

Bagian ini berisi tentang pembahasan hasil penelitian berupa deskripsi kemampuan literasi matematis soal aritmatika sosial berdasarkan gender yang didasarkan pada sub indikator literasi matematis. Deskripsi kemampuan literasi matematis materi aritmatika sosial berdasarkan gender yang didasarkan pada sub indikator literasi matematis dengan melihat sub indikator pada kemampuan literasi matematis berdasarkan teori yang dikemukakan oleh Polya yaitu: (1) siswa mampu mengidentifikasi masalah, (2) siswa mampu membuat rencana penyelesaian dengan tepat, (3) siswa mampu mengajukan rumus dan menetapkan penyelesaian dari suatu masalah dan, (4) siswa dapat menyelesaikan masalah yang dihadapi dan menarik sebuah kesimpulan.

Kemampuan literasi matematis pada subjek gender perempuan mampu menyelesaikan permasalahan yang diberikan peneliti sehingga subjek mampu mengungkap 4 sub indikator dari kemampuan literasi matematis untuk nomor 1. Sedangkan untuk soal nomor 2 subjek perempuan hanya mampu menyelesaikan sampai pada 3 sub indikator, sub indikator ke 4 tidak diselesaikan oleh subjek dikarenakan waktu untuk menjawab soal telah selesai. Hasil penelitian ini memiliki kesamaan dengan penelitian yang telah dilakukan oleh Baharuddin, dkk. (2017) bahwa siswa mampu menguasai konten matematika dalam mengerjakan soal literasi matematis. Selain itu, soal literasi matematis ini membuat para siswa mudah mengerjakan soal matematika meskipun dalam bentuk konten matematika seperti ruang dan bentuk, perubahan dan keterkaitan serta bilangan. Pada tes kemampuan literasi matematis yang menurut siswa sulit ternyata beberapa siswa tetap mampu untuk menyelesaikannya. Penelitian ini juga sejalan dengan penelitian yang dilakukan oleh Wulandari (2016) yang menyebutkan bahwa peserta didik perempuan memiliki gaya belajar yang bebas atau bervariasi sehingga lebih mampu berinteraksi dalam kelas dibandingkan dengan siswa laki-laki yang bersifat individual dan menyukai tantangan. Hasil penelitian ini didukung oleh penelitian yang dilakukan Huda \& Kencana (2013) dimana siswa yang memiliki IQ tinggi akan lebih mampu menyebutkan seluruh informasi, merencanakan langkah pemecahan masalah dan menjelaskan kembali masalah yang ada.

Adapun kemampuan literasi matematis pada subjek gender laki-laki hanya mampu mengungkap 3 sub indikator kemampuan literasi matematis saja, sub indikator yang ke 4 tidak diselesaikannya karena subjek laki-laki beranggapan ketika hasil tes telah diperoleh maka tidak perlu lagi dituliskan dengan kesimpulan dan alasan lainnya ialah saat mengerjakan soal subjek mengingat-ingat kembali soal yang pernah diberikan sehingga subjek menyelesaikan soal berdasarkan hasil ingatan-ingatan terhadap soal yang pernah dipelajarinya. Selain itu, subjek laki-laki masih keliru pada pembagian dan perkalian. Hasil 
penelitian ini memiliki kesamaan dengan penelitian yang dilakukan oleh Baharuddin \& Jumarniati (2021) yang menyatakan bahwa siswa masih kurang teliti dalam melakukan operasi hitung, lupa menuliskan tanda negatif pada hasil operasi hitung serta tidak menuliskan jawaban secara lengkap. Penelitian ini juga sejalan dengan yang dilakukan oleh Suryaprani, dkk. (2016) bahwa kemampuan literasi matematis yang dimiliki oleh siswa laki-laki dan perempuan berbeda, karena siswa laki-laki lebih memiliki suatu argumen yang kuat dan percaya diri yang lebih tinggi dibandingkan siswa perempuan. Hal ini juga didukung dengan penelitian yang dilakukan oleh Nafi'an (2011) yang menyatakan bahwa perbedaan laki-laki dan perempuan dalam belajar matematika sebagai berikut: 1) Laki-laki lebih unggul dalam penalaran, perempuan lebih unggul dalam ketepatan, ketelitian, kecermatan, dan keseksamaan berpikir. 2) Laki-laki memiliki kemampuan matematika dan mekanika yang lebih baik dari pada perempuan, perbedaan ini belum terlihat pada tingkat sekolah dasar namun akan terlihat jelas pada tingkat yang lebih tinggi. Sejalan dengan itu, Tasni \& Indrawati (2016) mengemukakan bahwa aspek kognitif pada gender perempuan dalam menyelesaikan masalah matematika lebih sangat cenderung hati-hati, ragu-ragu dan terstruktur. Sedangkan pada gender laki-laki dalam pemecahan masalah matematika cenderung lebih cepat dalam mengambil sikap, kurang sistematis dan kurang rapi. Pendapat tersebut menunjukkan kemampuan yang tinggi bagi anak laki-laki dalam hal matematika, namun perempuan lebih unggul dalam aspek efektifnya (tekun, teliti dan cermat).

Adapun temuan dalam penelitian ini adalah sekalipun subjek perempuan mampu menyelesaikan permasalahan dan mampu mengungkap sub indikator namun subjek perempuan masih keliru pada pembagian dan perkalian. Begitupun subjek laki-laki masih keliru pada pembagian dan perkalian. Subjek laki-laki sebenarnya telah memahami dan mampu menyelesaikan soal sampai pada tahap kesimpulan tetapi tidak menuliskan di kertas jawabannya karena menurutnya ketika hasil jawaban telah diperoleh maka tidak perlu lagi dituliskan dengan kesimpulan. Hal ini dipengaruhi oleh pola pikir dan penalaran subjek. Sehingga pada kertas jawabannya Subjek hanya menuliskan sampai pada sub indikator 3 .

\section{PENUTUP}

\section{Kesimpulan}

Kemampuan literasi Matematis siswa subjek gender perempuan dalam menyelesaikan soal aritmatika sosial menunjukkan bahwa subjek mampu mengerjakan dan menyelesaikan soal sesuai prosedur pengerjaan soal sampai selesai. Tes kemampuan literasi matematis mempunyai sub indikator yaitu (a) siswa mampu mengidentifikasi masalah dan membuat rencana penyelesaian, (b) siswa dapat membuat rencana penyelesaian dengan tepat, (c) siswa mampu mengajukan rumus dan menetapkan penyelesaian dari suatu masalah dan (d) siswa dapat menyelesaikan permasalahan dan 
menyimpulkannya, dari hasil tes kemampuan literasi matematis menunjukkan subjek mampu mengungkap 4 sub indikator kemampuan literasi matematis untuk soal nomor 1 tetapi untuk soal nomor 2 subjek hanya mampu mengungkap 3 sub indikator kemampuan literasi matematis, dikarenakan waktu untuk mengerjakan soal telah selesai sehingga subjek tidak sempat melanjutkan sampai pada tahap kesimpulan permasalahan yaitu sub indikator ke 4, subjek juga masih keliru pada pembagian dan perkalian.

Kemampuan literasi matematis subjek gender laki-laki dalam menyelesaikan soal aritmatika sosial menunjukkan bahwa subjek mengerjakan dan menyelesaikan soal sesuai prosedur pengerjaan soal hanya saja tidak sampai pada tahap menyimpulkan permasalahan yaitu sub indikator ke 4. Tes kemampuan literasi matematis mempunyai sub indikator yaitu: (a) siswa mampu mengidentifikasi masalah dan membuat rencana penyelesaian, (b) siswa dapat membuat rencana penyelesaian dengan tepat, (c) siswa mampu mengajukan rumus dan menetapkan penyelesaian dari suatu masalah dan (d) siswa dapat menyelesaikan permasalahan dan menyimpulkannya, dari hasil tes kemampuan literasi matematis menunjukkan bahwa subjek hanya mampu mengungkap 3 sub indikator kemampuan literasi matematis untuk soal nomor 1 subjek beranggapan bahwa ketika hasil dari pengerjaan soal telah didapatkan maka tidak perlu di tuliskan kesimpulan dari jawaban yang didapat sedangkan untuk soal nomor 2 subjek mengerjakannya dari hasil pengetahuan terhadap soal yang pernah diberikan. Selain itu subjek masih keliru pada pembagian dan perkalian.

\section{Saran}

Rekomendasi dalam penelitian ini adalah Soal literasi matematis bisa diterapkan di sekolah untuk meningkatkan kemampuan matematika siswa dan soal literasi dapat di pelajari siswa dengan baik agar kedepannya dapat berkembang.

\section{DAFTAR PUSTAKA}

Agninditya, F. (2014). Analisis Kesalahan dan Kesulitan Siswa dalam Menyelesaikan Soal Uraian Pokok Bahasan Trigonometri Kelas X.IIS di SMA N 1 Rembang. Prosiding Mathematics and Sciences Forum 2014.

Baharuddin, M. R. \& Jumarniati. (2021). Investigasi Kesalahan Siswa Dalam Menyelesaikan Masalah Bilangan Cacah: Kasus Pada Kesalahan Prosedural Dan Kesalahan Konsep. Proximal: Jurnal Penelitian Matematika Dan Pendidikan Matematika, 4(1), 80-86.

Baharuddin, M. R., Fitriani, A., \& Jumarniati. (2017). Efektivitas Pendekatan Problem Posing Setting Kooperatif Terhadap Kemampuan Literasi Matematis. Pedagogy: Jurnal Pendidikan Matematika, 2(2), 128

Evijayanti, W \& Khotimah, R. P. (2018). Analisis Kesulitan Siswa SMP dalam Menyelesaikan Soal Cerita Aritmatika Sosial. Prosiding Seminar Nasional Matematika dan Pendidikan Matematika (Sesiomadika), 295-302

Fitri, N. M. A., Adirakasiwi, A. G., \& Utami, M. R. (2017). Analisis Kesulitan Siswa dalam 
Menyelesaikan Soal Cerita Matematika pada Siswa SMP, 3(2), 1-14.

Hamalik, O. (2013). Proses Belajar Mengajar. Jakarta : PT. Bumi Aksara

Harahap, S. S. (2010). Analisa Kritis atas Laporan Keuangan. Cet. 11. Jakarta : PT Raja Grafindo Persada

Hoang, T. N. (2008). The Effects Of Grade Level, Gender and Ethnicity On Attitude and Learning Exprerimences of Girls and Boys. ISSN: Journal of Research on Technology in education, 41 (3), 253-276.

Huda, N. \& Kencana, A. G. (2013). Analisis Kesulitan Siswa Berdasarkan Kemampuan Pemahaman dalam Menyelesaikan Soal Cerita pada Materi Kubus dan Balok Di Kelas VIII SMP Negeri 30 Muaro Jambi. Prosiding Semirata FMIPA Universitas Lampung, 1(1): 595-606

Jamal, F. (2014). Analisis Kesulitan Belajar Siswa dalam Mata Pelajaran Matematika pada Materi Peluang Kelas XI IPA SMA Muhammadiyah Meulaboh Johan Pahlawan. Jurnal Pendidikan Matematika, 1(1), 18-36.

Nafi'an, M. I. (2011). Kemampuan Siswa Dalam Menyelesaikan Soal Cerita Ditinjau Dari Gender Di Sekolah Dasar. Prosiding Seminar Nasional Matematika dan Pendidikan Matematika dengan tema Matematika dan Pendidikan Karakter dalam Pembelajaran. ISBN: 978-97916353-6-3.

Nugraha, S. A. \& Setiawan, R. (2016). Perancangan Sistem Informasi Pengolahan Administrasi Keuangan Sekolah Menengah Pertama Islam Terpadu Assalam Garut. Jurnal Algoritma Sekolah Tinggi Teknologi Garut. ISSN: 2302-7339, 13(1), 320-332.

OECD. (2013). PISA 2012 Results in Focus: What 15-year-olds know and what they can do with what they know. New York: Columbia University

Ojose, B. (2011). Mathematics Literacy: Are We Able to Put the Mathematics We Learn into Everyday Use?. Journal of Mathematics Education, 4(1).

Puspitasari. (2015). Jurnal Pendidikan Analisis Kesulitan Menyelesaikan Soal Cerita Materi Sistem Persamaan Linear Dua Variabel di SMP.

Romdhoni, A. (2013). Al-Qur'an dan Literasi. Depok: Literatur Nusantara.

Santrock, W. J. (2008). Psikologi Pendidikan. Jakarta: Kencana.

Saradevi. (2013). Penerapan Aritmetika Sosial dalam Kehidupan Sehari-hari. Diakses tanggal $5 \quad$ Mei 2020. https://saradevipalit.wordpress.com/2013 /08/11/penerapan-matematika-dalamkehidupan-sehari-hari

Sari, N. \& Wardani, R. (2015). Pengelolaan dan Analisis Data Statistik dengan SPSS. (Ed. 1). Yogyakarta: Deepublish.

Setyawan, I. A. (2018). Kupas Tuntas Jenis dan Pengertian Literasi. Diakses pada 10 Agustus 2018. https://gurudigital.id/jenispengertian-literasi-adalah

Setyono, D. (2013). Kesalahan Menyelesaikan Soal Matematika dalam Bentuk Cerita Pokok Bahasan Aritmetika Sosial. Makalah disajikan di Seminar Nasional Pendidikan Matematika. Universitas Muhammadiyah Surakarta: 65-74.

Shalikhah, M. (2019). Analisis Kesulitan Siswa SMP Negeri 3 Pleret pada Materi Aritmatika Sosial. Academy of Education Journal, 10(1), 44-54.

Suryaprani, M. W., Suparta, I. N., \& Suharta, I. G. P. (2016). Hubungan Jenis Kelamin, Literasi Matematika, dan Disposisi Matematika Terhadap Prestasi Belajar Matematika 
Peserta Didik SMA Negeri di Denpasar. In Prosiding Seminar Nasional MIPA

Susanto, A. (2013). Teori Belajar dan Pembelajaran di Sekolah Dasar. Jakarta: Kencana Prenada Media Group.

Suyono \& Hariyanto. (2011). Belajar dan Pembelajaran Teori dan Konsep Dasar. Bandung: Rosdakarya. h.39.

Tasni,N \& Indrawati. (2016). Analisis kemampuan pemecahan masalah berdasarkan tingkat kompleks masalah dan perbedaan gender. Jurnal Saintifik Vol.2 No.1 Januari 2016.

Widyaningrum, I. (2015). Desain Pembelajaran Materi Aritmatika Sosial dengan Model Permainan Pasar-Pasaran. Prosiding Seminar Nasional Pendidikan Matematika (SNAPTIKA) 2015.

Wiyartimi, W. R. \& Ratnaningsih. (2010). Diagnosis Kesulitan Belajar Matematika Siswa pada Materi Trigonometri Rumusrumus segitiga di Kelas X SMA Negeri 50 Jakarta. JMAP, 9(2).
Wulandari, N. P. M. (2016). Deskripsi Kompetensi Strategis Matematis Kelas VII SMP Negeri 1 Palopo Berdasarkan Gender. Academy of Education Journal, 6(1), 118119.

Yanti, A. (2014). Analisis Kesulitan Siswa dalam Memecahkan Masalah Matematika pada Materi Aritmatika Sosial di Kelas VII SMP Negeri 2 Banda Aceh Tahun Ajaran 2013/2014. Diakses dari https://etd.unsyiah.ac.id/index.php?p=sh ow_detail\&id $=8856$

Yumniyati, K (2016). Pengaruh jenis kelamin terhadap kemampuan berpikir kreatif siswa kelas $X$ pada materi geometri dikontrol dengan kemampuan spasial di SMAN 13 Semarang tahun pelajaran 2015/2016. Diakses pada 25 Juli 2018 dari: http://eprints.walisongo.ac.id/5904/1/123 511043.pdf

Zakiah, L. \& Lestari, I. (2019). Berpikir Kritis Dalam Konteks Pembelajaran. Bogor: Erzatama Karya Abadi. 